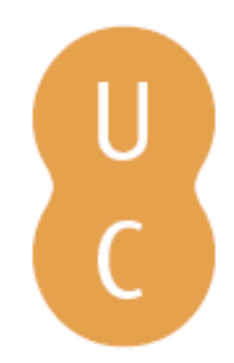

\title{
Rompalina
}

\section{Biomass burning emissions using the Sentinel 2 small fire database}
Autor(es): $\quad$ Ramo, Rubén; Roteta, Ekhi; Bistinas, loannis; Bastarrika, Aitor; Chuvieco, Emilio; Werf, Guido van der

Publicado por: Imprensa da Universidade de Coimbra

URL

persistente: URI:http://hdl.handle.net/10316.2/44619

DOI: $\quad$ DOI:https://doi.org/10.14195/978-989-26-16-506_102

Accessed : $\quad$ 26-Apr-2023 13:44:50

A navegação consulta e descarregamento dos títulos inseridos nas Bibliotecas Digitais UC Digitalis, UC Pombalina e UC Impactum, pressupõem a aceitação plena e sem reservas dos Termos e Condições de Uso destas Bibliotecas Digitais, disponíveis em https://digitalis.uc.pt/pt-pt/termos.

Conforme exposto nos referidos Termos e Condições de Uso, o descarregamento de títulos de acesso restrito requer uma licença válida de autorização devendo o utilizador aceder ao(s) documento(s) a partir de um endereço de IP da instituição detentora da supramencionada licença.

Ao utilizador é apenas permitido o descarregamento para uso pessoal, pelo que o emprego do(s) título(s) descarregado(s) para outro fim, designadamente comercial, carece de autorização do respetivo autor ou editor da obra.

Na medida em que todas as obras da UC Digitalis se encontram protegidas pelo Código do Direito de Autor e Direitos Conexos e demais legislação aplicável, toda a cópia, parcial ou total, deste documento, nos casos em que é legalmente admitida, deverá conter ou fazer-se acompanhar por este aviso.

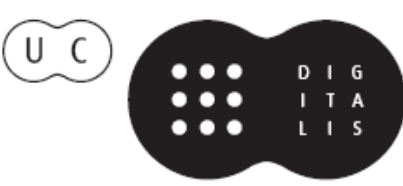




\section{ADVANCES IN}

\section{FOREST FIRE RESEARCH}

\section{8}

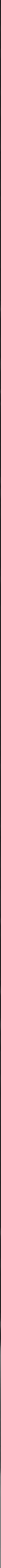




\title{
Biomass burning emissions using the Sentinel 2 Small Fire Database
}

\author{
Rubén Ramo ${ }^{1 *}$; Ekhi Roteta2 ${ }^{2}$ Ioannis Bistinas ${ }^{3}$; Aitor Bastarrika²; Emilio \\ Chuvieco ${ }^{1}$; Guido van der Werf ${ }^{3}$ \\ ${ }^{1}$ Enviromental Remote Sensing Research Group, Department of Geology, Geography and the \\ Environment, University of Alcalá. Colegios 2, 28801 Alcalá de Henares, Spain. \\ \{ruben.ramo@uah.es*,emilio.chuvieco@uah.es\} \\ ${ }^{2}$ Department of Mining and Metallurgical Engineering and Materials Science, School of \\ Engineering of Vitoria-Gasteiz. University of the Basque Country UPV/EHU, Nieves Cano 12, 7 \\ 01006 Vitoria-Gasteiz, Spain. \{ekhi.roteta@gmail.com, aitor.bastarrika@ehu.es\} \\ ${ }^{3}$ VU University, Faculty of Sciences, Department of Earth Sciences, 1081 HV, Amsterdam, \\ Netherlands.\{i.bistinas@vu.nl,guido.vander.werf@vu.nl\}
}

\begin{abstract}
Burned area (BA) estimates based on moderate resolution (500 meters) MODIS instruments show that globally, 3,500,000 hectares burns each year. MODIS has difficulty capturing fires smaller than 25 ha and studies estimate this lost variability up to $24 \%$. These estimates are highly uncertain.

We use burnt area from the Sentinel 2 Small Fire Database (SFD) at 20m spatial resolution for six tiles $\left(5 \times 5^{\circ}\right)$ in northern hemisphere Africa in areas that burn frequently. We find that in large fires $(>100 \mathrm{ha})$, MODIS (MCD64) and SFD show a reasonable agreement (92\%). However, MODIS misses most small fires ( $<25$ ha) that add an additional $37 \%$ area burnt. SFD reveals a total burnt area that is $50 \%$ higher than MODIS for the studied areas.

We then calculate fire emissions from the SFD and we compare to the Global Fire Emissions Database GFED4 and GFED4s. The contribution of small fires in terms of total burned area and emissions has been significantly underestimated and we find emissions up to 56\% higher than GFED4 and 37\% higher than GFED4s for this regions. This analysis highlights the importance of accounting for small fires for both burned area and fire emissions.
\end{abstract}

Keywords: Sentinel 2, MODIS, small fires, burned area, emissions

\section{Introduction}

Fire is one of the most important factors in the ecosystem disturbance. It affects to the landscape, vegetation structure, biodiversity and also to humans (Kloster et al. 2012; Mouillot et al. 2014). As a result of the combustion, greenhouse gasses are emitted to the atmosphere being an important part of the carbon cycle making alterations to the atmospheric composition and hence affecting to the climate (van der Werf et al. 2010).

Because of these reasons fire disturbance is considered one of the Essential Climate Variables (ECVs) by the Global Climate Observing System (GCOS) (Bojinski et al. 2014). In this context, there are multiple agencies, projects and studies that focus on the cartography of burned areas in order to assess the impact of fires and to provide reliable information to the climate modelling community based on remote sensing data. One of them is the Fire_cci project, carried out by the European Spatial Agency in the frame of the Climate Change Initiative (CCI) program (Hollmann et al. 2013). The Fire_cci main objective is to elaborate global burned area maps in long time series.

There are a wide variety of sensors and methods to estimate the burned area. The traditional approach to provide global burned area mapping is by the use of moderate resolution images such as 
Advance very high resolution radiometer (AVHRR) (Riaño et al. 2007), VEGETATION (Tansey et al. 2008), Moderate Resolution Imaging Spectrometer (MERIS) (Alonso-Canas and Chuvieco 2015) or Moderate Resolution Image Spectroradiometer (MODIS) (Chuvieco et al. 2018; Giglio et al. 2006; Roy et al. 2008). The products developed by these sensors have been widely used to make emissions estimations (Chuvieco et al. 2016; Giglio et al. 2013; Van Der Werf et al. 2017), analyze the human impact on fire (Hantson et al. 2015) or to study the fire regimes (Archibald et al. 2010).

One of the drawbacks of these products is the high omission mainly related to the spatial resolution of these products $(1 \mathrm{~km}$ to $300 \mathrm{~m}$ ). The influence of the small fires have been studied (Randerson et al. 2012) in terms of the total burned and carbon emitted, concluding that it represents a significant part of the total burned, but there is uncertainty around these estimations. Nowadays, thanks to the advances in computing science and the new generation of high-resolution satellite images such as Landsat or Sentinel 2 (10-30 meters resolution) is possible to provide better estimations of fire impact.

There are several studies that perform burned area based on Landsat (Bastarrika et al. 2014) or Sentinel (Fernández-Manso et al. 2016; Huang et al. 2016), but none of them have been applied to a continental scales or to a long time period. In this frame, the Fire_cci project has developed a new product named Small Fire Database (SFD) using Sentinel 2 images. The database extent covers the African continent in 2016 at 20 meter resolution and is planned to be released in the next months.

The objective of this paper is to analyze the potential of the SFD in six different $5 \times 5^{\circ}$ regions of the north of Africa using the first version of the database that only comprises the first nine months of the year. A comparison with the MCD64 product was performed in terms of total burned area, fire size distribution, and emissions performed by the Global Fire Emissions Dataset (GFED) (Van Der Werf et al. 2017).

\section{Methods}

\subsection{Burned area databases}

The MCD64 product provides the burned information extracted from MODIS reflectances from Terra and Aqua at 500 meter resolution (Giglio et al. 2009). This product is available from November of 2000 until now in monthly layers and encodes the day of burned together with the uncertainty for the burned pixels. In general terms, the product detects the burned area using a temporal composites of vegetation indices based on the shortwave infrared (SWIR) wavelength applied to a temporal series. The algorithm also uses the active fire information from MODIS to characterize the burned signal and to extend the segmentation to the whole image, making the thresholds able to regional adaptation and hence to multiple fire conditions.

One of the most widely used emission product is GFED (Van Der Werf et al. 2017) that is extensively used for climate, atmospheric and biochemical modelling (Aouizerats et al. 2015; Schwietzke et al. 2016). In this frame, the MCD64 product is one of his main source of information used to perform the emissions estimations from the forest fires. GFED use the CASA (CarnegieAmes-Stanford Approach) to derive the ecosystem productivity through the use of remote sensing data for finally produce a global estimation of carbon emissions and other trace gases. There are different versions of this database, the last versions are GFED4 and GFED4s. Both use MCD64 as burned area input, but GFED4s also include an estimation of the burned fraction caused by the small fires. This estimation comes from the influence of the active fires that have enough sensitivity to detect fires below of their original resolution.

The SFD uses Sentinel 2-MSI data at 20 meter resolution to estimate the burned area in Africa (Roteta et al. 2018). It has been applied in the north of Africa for the nine first months of 2016 in a first phase, but the processing chain has been extended for the entire year and continent. Here a selection of six different study areas (Figure 1) were selected to test the potential of the database. 


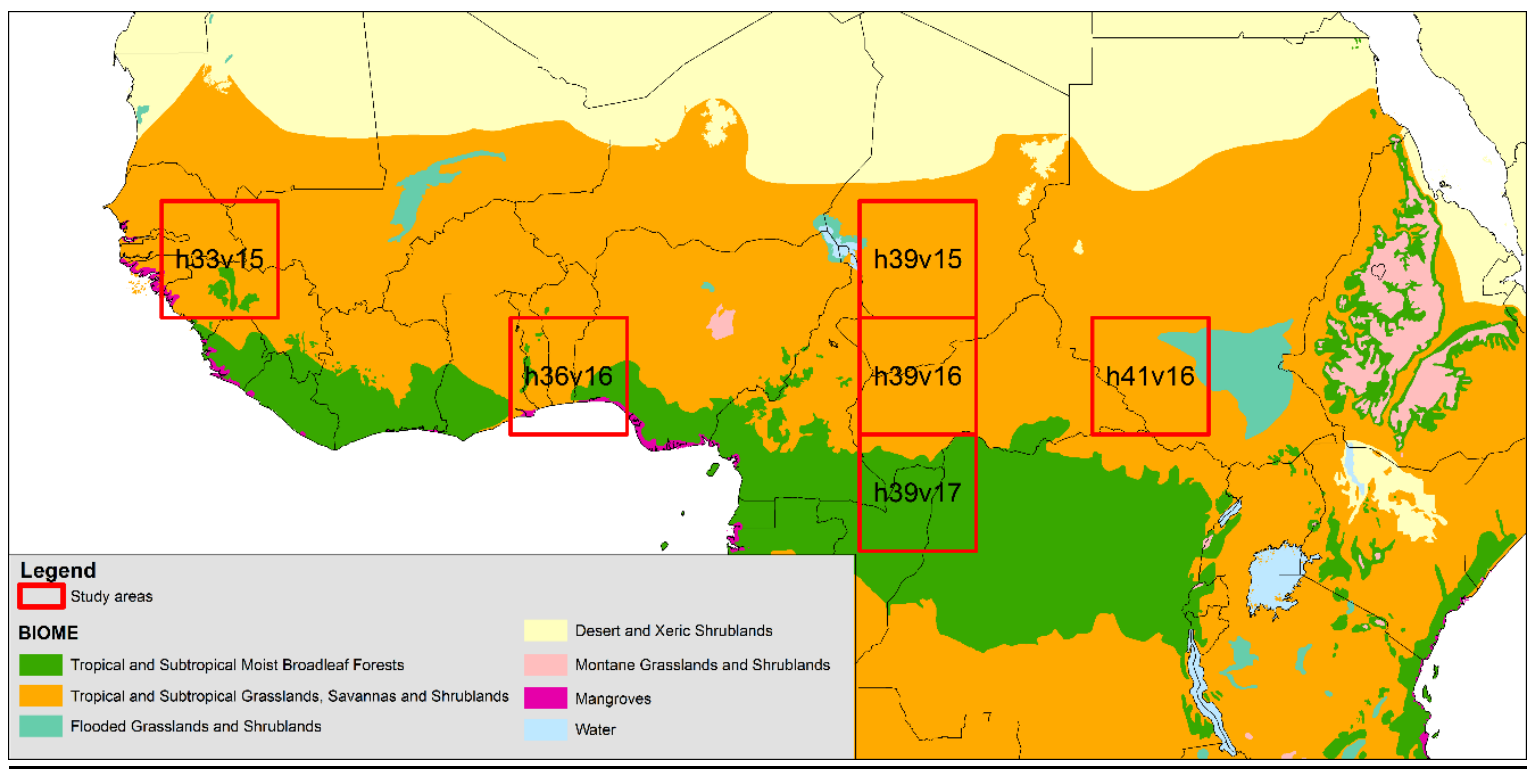

Figure 1 - Locations of the study area

The algorithm derives the burned area using a hybrid multitemporal approach classifying pairs of images from the available images. The structure of the algorithm has three different steps. First, a group of burned area indices were performed. After that an initial segmentation of the image using those indices to derive an early burned area. This result is crossed with the active fire observations in order to extract some high probability burned pixels or seeds. The seed is introduced in a probability distribution function of two different indices normalized burned ratio (NBR) and the mid-infrared burned index (MIRBI). Finally following the distribution function the pixels are classified using a certain threshold.

This version SFD have been validated following a systematic sampling scheme using 27 test areas. The perimeters were generated in a first step using a semiautomatic burned area mapping tool (Bastarrika et al. 2014) to finally perform a visual analysis to guarantee the quality of the data. The way to obtain the burned area from the test perimeters was de same used in the Fire_cci project (Padilla and Chuvieco 2014; Padilla et al. 2015) and follows the CEOS-CalVal protocol. The results obtained in the validation shows a commission error of $7.3 \%$ while omission is $18.4 \%$, further details are shown in Roteta et al (2018).

\subsection{Data processing}

To carry out the comparisons at pixel level the MCD64 collection 6 were used. MODIS products are developed under the observations of two different satellites (Terra and Aqua), thus the revisited period is significantly higher (twice per day) than the one used by the SFD (once per ten days). Because the temporal resolution, pixels that have a contiguous day of burned can be considered a single fire event and the changes in the day of burned are due to the fire spread (Archibald and Roy 2009). To separate individual fires for MODIS a flood algorithm was used to connect fires that have a spatial connectivity in a $3 \times 3$ window within a temporal frame of four days. Once this process is over, the next step is to individualize the fires labelling each one with a unique value performing at the same time the fire size. To do so pixels with a similar day of burned connected by $3 \times 3$ window are considered one single event. The fire size was divided in 7 different ranks: 0.04 ha, 0.04-1 ha, 1-5 ha, 5-25 ha, 2550 ha, 50-100 ha, >100 ha.

For the emissions estimation, the SFD was converted to $0.25^{\circ}$ summarizing the total amount of burned area for each grid cell. This information was used to replace the source of burned of the GFED model, which used to be MCD64 collection 5. The emission was performed for three databases SFD, GFED4, and GFED4s using the same parameters to make able the comparison. 


\section{Results}

The next figure shows the amount of burned area observed in the six test areas ordered by fire size.

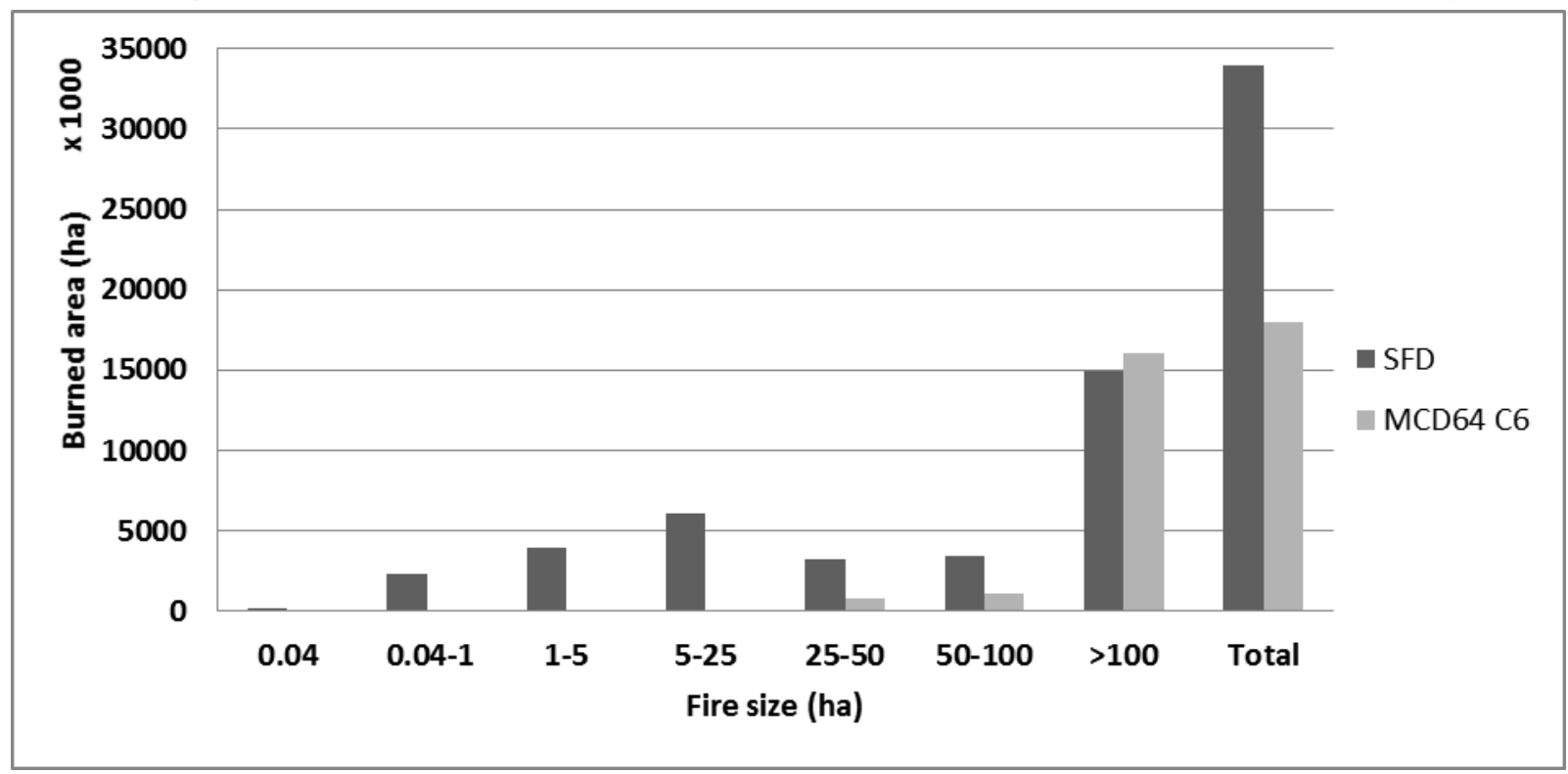

Figure 2 - Total burned by size for the six test areas.

The total burned observed for MCD64 is $47 \%$ lower than the estimations through SFD. The fires below the MODIS resolution represent the $37 \%$ of the total burned. SFD also detect more burned area between 25-100 ha, while for fires bigger than 100 ha MODIS detect slightly more burned area.

Figure 3 shows the fire counts for single fire events for both products. SFD shows a higher number of fires in all the range size including the $>100$ fire size. The number of fire counts shows an exponential trend where the maximum is reached with fires between 0.04-1 ha.

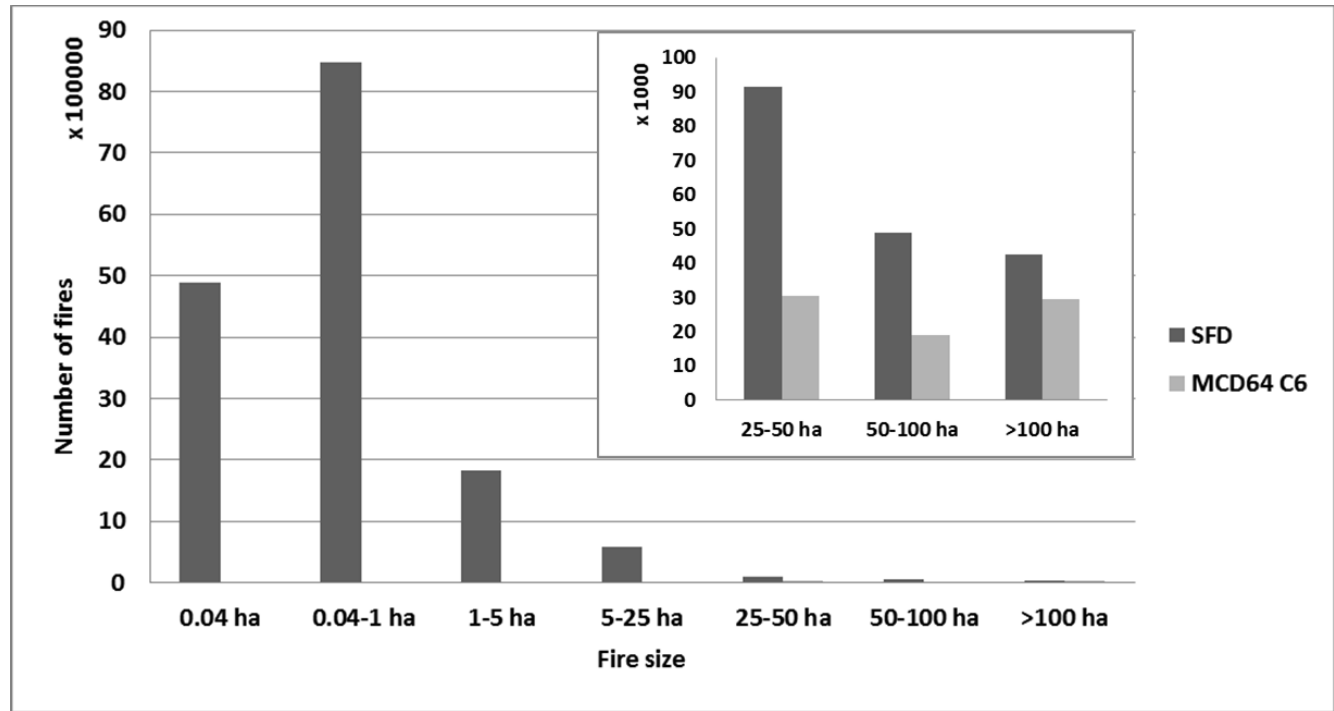

Figure 3 - Number of individual fires for MCD64 and SFD

The next figure shows the total burned observed for the three fire databases along the year. The observed trends are similar for all products but the amount of burned area not, being SFD the database that shows more followed by GFED4s and GFED4. 


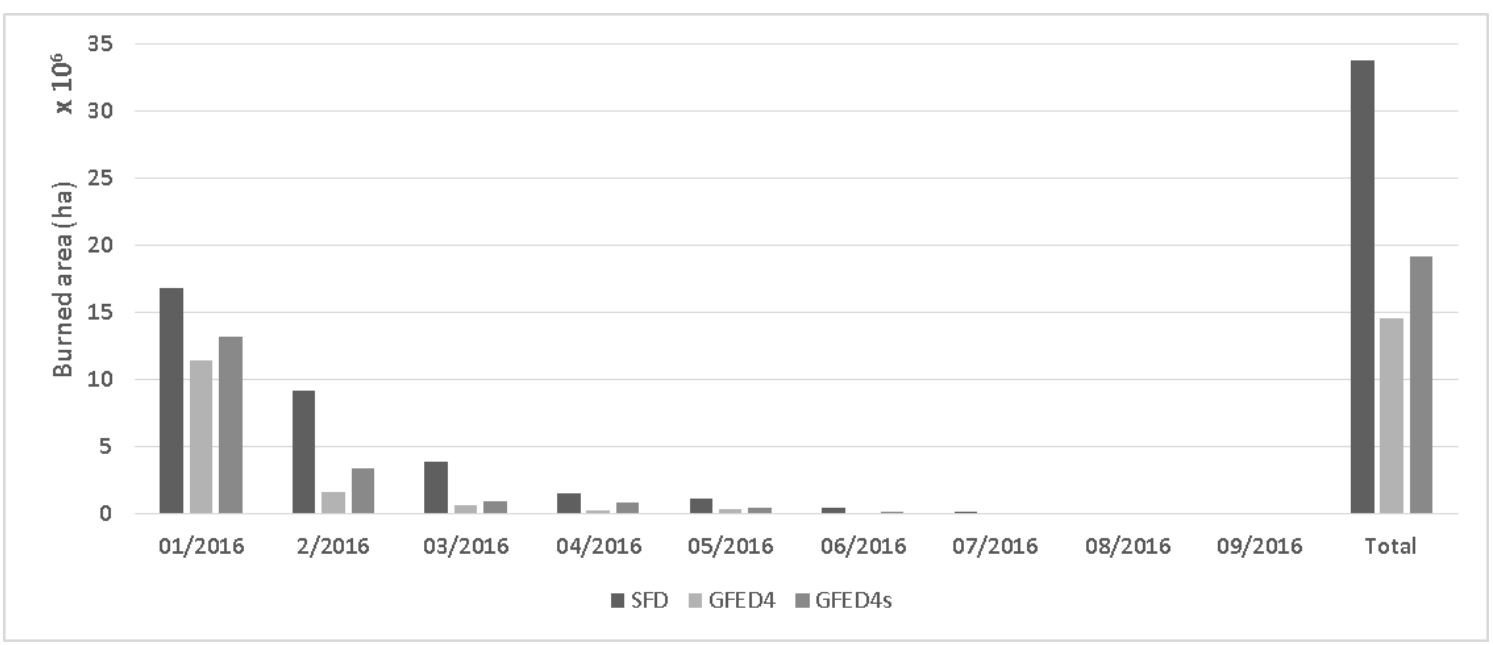

Figure 4 - Burned area distribution for SFD, GFED4 and GFED4s.

The total burned area founded by SFD is 57\% higher than for GFED4 and 43\% more than GFED4s. The higher differences are observed after the fire season in January, especially in February and March.

The emissions derived from these burned area databases are shown in figure 5. The observed trends are similar to those observed in burned area. The amount of carbon emitted by SFD is $56 \%$ higher than GFED4 and 37\% in comparison with GFED4s.

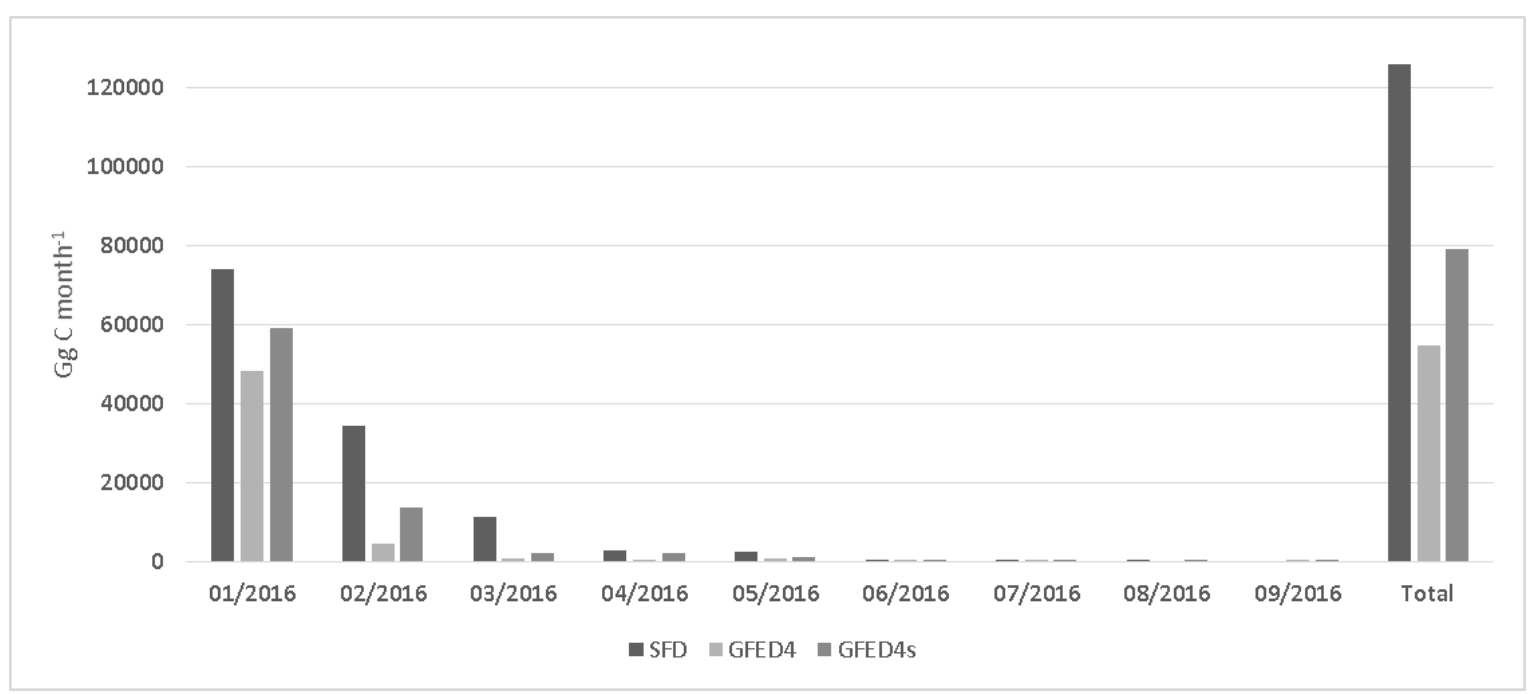

Figure 5 - Emissions for SFD, GFED4 and GFED4s

\section{Discussion and conclusions}

This study analyzes six different tiles of the new SFD produced by the Fire_cci project. We compared the SFD at pixel level with the standard product MCD64 collection 6 in terms of total burned, number of fires and fire size distribution. We derive emissions at $0.25^{\circ}$ grid using the GFED model and we show a comparison between SFD, GFED4 and GFED4s.

The results obtained in the comparison at pixel level reveal that there is a significant difference between the SFD and MCD64. Those differences represent almost the 50\% of the total burned. Between both products, there is an agreement solely in the big fires ( $>100$ ha) with only $8 \%$ difference. For the rest of the fire sizes, MODIS detects less burned area even above the minimum resolution that the sensor can detect (25-100 ha). The total burned area is 29\% less than for the Sentinel product for 
these fire intervals. The underestimation of the MCD64 product is related in part to the influence of the small fires but also with the mixed signatures that comes from other surface reflectances.

In terms of number of fires the SFD detect more in all the observed intervals, even in the biggest fire range where MCD64 shows more burned area. This indicates that the SFD shows smaller and more fragmented fires than MODIS because of the resolution effect. The smallest fire categories $(0.04-$ $1 \mathrm{ha}$ ) represent less than the $10 \%$ of the total burned, but in number of fires are the $84 \%$ of the total fire events. In this context, small fires ( $<25 \mathrm{ha}$ ) are $98.8 \%$ of the total ignitions and group $37 \%$ of the total burned area with events of 0.04-1 ha being the most common fire size (53\% of the total).

The differences in amount of burned area between GFED4 and SFD is 57\% while for GFED4s is $43 \%$. For GFED4 the differences are higher than the observed at pixel level (50\%) because this model uses the data provided by the collection 5 instead of the sixth from the MCD64. Furthermore, when including small fires in GFED (GFED4s), the emissions are still lower than from the SFD. Those differences, located mainly between February and May, are related with the sensitivity of the active fire observations. GFED4s estimates the contribution of the small fires using the fraction of hotspots that are located out of the burned area from the MCD64. The basic principle is that the active fires observations are more sensitive to fires than their native resolution. That approximation is a result of a statistical analysis, while SFD is purely based on higher resolution observation. The differences in terms of emissions between the analyzed products are slightly lower than the one founded in burned area. Emissions are dependent on other factors like the biomass or land cover. In this case, the estimations provided by GFED4s are 6\% closer to the SFD than the burned area approximation.

Despite this study is limited in temporal and spatial extent, the results confirm the evidences of other researches (Randerson et al. 2012) that small fires have a significant impact in terms of burned area and emissions. To better characterize the role of the small fires and their influence on climate, further efforts to develop long time series of high resolution burned area maps are vital.

\section{References}

Alonso-Canas, I., \& Chuvieco, E. (2015). Global Burned Area Mapping from ENVISAT-MERIS and MODIS active fire data. Remote Sensing of Environment, 163, 140-152

Aouizerats, B., Van Der Werf, G.R., Balasubramanian, R., \& Betha, R. (2015). Importance of transboundary transport of biomass burning emissions to regional air quality in Southeast Asia during a high fire event. Atmospheric Chemistry and Physics, 15, 363-373

Archibald, S., Nickless, A., Govender, N., Scholes, R.J., \& Lehsten, V. (2010). Climate and the interannual variability of fire in southern Africa: a meta-analysis using long-term field data and satellitederived burnt area data. Global Ecology and Biogeography, 19, 794-809

Archibald, S., \& Roy, D.P. (2009). Identifying individual fires from satellite-derived burned area data. In, Geoscience and Remote Sensing Symposium,2009 IEEE International,IGARSS 2009 (pp. III160-III-163)

Bastarrika, A., Alvarado, M., Artano, K., Martinez, M.P., Mesanza, A., Torre, L., Ramo, R., \& Chuvieco, E. (2014). BAMS: A Tool for Supervised Burned Area Mapping Using Landsat Data. Remote Sensing, 6, 12360-12380

Bojinski, S., Verstraete, M., Peterson, T.C., Richter, C., Simmons, A., \& Zemp, M. (2014). The concept of essential climate variables in support of climate research, applications, and policy. Bulletin of the American Meteorological Society, 95, 1431-1443

Chuvieco, E., Lizundia-Loiola, J., Pettinari, M.L., Ramo, R., Padilla, M., Tansey, K., Mouillot, F., Laurent, P., Storm, T., Heil, A., \& Plummer, S. (2018). Generation and analysis of a new global burned area product based on MODIS $250 \mathrm{~m}$ reflectance bands and thermal anomalies. Earth System Science Data, 1-24 
Chuvieco, E., Yue, C., Heil, A., Mouillot, F., Alonso-Canas, I., Padilla, M., Pereira, J.M., Oom, D., \& Tansey, K. (2016). A new global burned area product for climate assessment of fire impacts. Global Ecology and Biogeography, 25, 619-629

Fernández-Manso, A., Fernández-Manso, O., \& Quintano, C. (2016). SENTINEL-2A red-edge spectral indices suitability for discriminating burn severity. International Journal of Applied Earth Observation and Geoinformation, 50, 170-175

Giglio, L., Loboda, T., Roy, D.P., Quayle, B., \& Justice, C.O. (2009). An active-fire based burned area mapping algorithm for the MODIS sensor. Remote Sensing of Environment, 113, 408-420

Giglio, L., Randerson, J.T., \& Werf, G.R. (2013). Analysis of daily, monthly, and annual burned area using the fourth-generation global fire emissions database (GFED4). Journal of Geophysical Research: Biogeosciences, 118, 317-328

Giglio, L., Van der Werf, G., Randerson, J., Collatz, G., \& Kasibhatla, P. (2006). Global estimation of burned area using MODIS active fire observations. Atmospheric Chemistry and Physics, 6, 957974

Hantson, S., Lasslop, G., Kloster, S., \& Chuvieco, E. (2015). Anthropogenic effects on global mean fire size. International Journal of Wildland Fire, 24, 589-596

Hollmann, R., Merchant, C., Saunders, R., Downy, C., Buchwitz, M., Cazenave, A., Chuvieco, E., Defourny, P., De Leeuw, G., \& Forsberg, R. (2013). The ESA climate change initiative: Satellite data records for essential climate variables. Bulletin of the American Meteorological Society, 94, 1541-1552

Huang, H., Roy, D.P., Boschetti, L., Zhang, H.K., Yan, L., Kumar, S.S., Gomez-Dans, J., \& Li, J. (2016). Separability analysis of Sentinel-2A multi-spectral instrument (MSI) data for burned area discrimination. Remote Sensing, 8, 873

Kloster, S., Mahowald, N., Randerson, J., \& Lawrence, P. (2012). The impacts of climate, land use, and demography on fires during the 21st century simulated by CLM-CN. Biogeosciences, 9

Mouillot, F., Schultz, M.G., Yue, C., Cadule, P., Tansey, K., Ciais, P., \& Chuvieco, E. (2014). Ten years of global burned area products from spaceborne remote sensing - A review: Analysis of user needs and recommendations for future developments. International Journal of Applied Earth Observation and Geoinformation, 26, 64-79

Padilla, M., \& Chuvieco, E. (2014). ESA CCI ECV Fire Disturbance - Product Validation Report II Results from the Global Sample. In. http://www.esa-fire-cci.org/documents

Padilla, M., Stehman, S.V., Ramo, R., Corti, D., Hantson, S., Oliva, P., Alonso-Canas, I., Bradley, A.V., Tansey, K., \& Mota, B. (2015). Comparing the accuracies of remote sensing global burned area products using stratified random sampling and estimation. Remote Sensing of Environment, 160, 114-121

Randerson, J., Chen, Y., Werf, G., Rogers, B., \& Morton, D. (2012). Global burned area and biomass burning emissions from small fires. Journal of Geophysical Research: Biogeosciences, 117

Riaño, D., Moreno Ruiz, J., Isidoro, D., \& Ustin, S. (2007). Global spatial patterns and temporal trends of burned area between 1981 and 2000 using NOAA-NASA Pathfinder. Global Change Biology, $13,40-50$

Roteta, E., Bastarrika, A., Storm, T., \& Chuvieco, E. (2018). Development of a Sentinel-2 Burned Area algorithm: generation of a Small Fire Database for Northern Hemisphere Tropical Africa (Under review). Remote Sensing of Environment

Roy, D., Boschetti, L., Justice, C., \& Ju, J. (2008). The collection 5 MODIS burned area productGlobal evaluation by comparison with the MODIS active fire product. Remote Sensing of Environment, 112, 3690-3707 
Schwietzke, S., Sherwood, O.A., Bruhwiler, L.M., Miller, J.B., Etiope, G., Dlugokencky, E.J., Michel, S.E., Arling, V.A., Vaughn, B.H., \& White, J.W. (2016). Upward revision of global fossil fuel methane emissions based on isotope database. Nature, 538, 88

Tansey, K., Grégoire, J.M., Defourny, P., Leigh, R., Pekel, J.F., Van Bogaert, E., \& Bartholomé, E. (2008). A new, global, multi-annual (2000-2007) burnt area product at $1 \mathrm{~km}$ resolution. Geophysical Research Letters, 35

van der Werf, G.R., Randerson, J.T., Giglio, L., Collatz, G., Mu, M., Kasibhatla, P.S., Morton, D.C., DeFries, R., Jin, Y.v., \& van Leeuwen, T.T. (2010). Global fire emissions and the contribution of deforestation, savanna, forest, agricultural, and peat fires (1997-2009). Atmospheric Chemistry and Physics, 10, 11707-11735

Van Der Werf, G.R., Randerson, J.T., Giglio, L., Van Leeuwen, T.T., Chen, Y., Rogers, B.M., Mu, M., Van Marle, M.J., Morton, D.C., \& Collatz, G.J. (2017). Global fire emissions estimates during 1997-2016. Earth System Science Data, 9, 697 